\author{
Gupta et al., Afr J Tradit Complement Altern Med. (2013) 10(4):59-65 \\ http://dx.doi.org/10.4314/ajtcam.v10i4.10
}

\title{
ETHNO-BOTANICAL STUDY OF MEDICINAL PLANTS OF PADDAR VALLEY OF JAMMU AND KASHMIR, INDIA
}

\author{
Sushil Kumar Gupta, ${ }^{1}$ OM Prakash Sharma, ${ }^{2}$ Narinder Singh Raina ${ }^{3}$ and Sandeep Sehgal ${ }^{4}$ \\ ${ }^{1,3,4}$ Division of Agroforestry, Sher-e-Kashmir University of Agricultural Sciences \& Technology of \\ Jammu, P.O. Chatha, Jammu, 180009, J\&K, INDIA \\ ${ }^{2}$ Conservator of Forests, Department of Forests, Government of J\&K, INDIA \\ Email:sushilgupta67@rediffmail.com
}

\begin{abstract}
The Paddar Valley, historically known as Sapphire Valley situated in Kishtwar district, is a prime landmark in the Jammu region of J\&K state and is known for its rich cultural and plant diversity because of diverse habitats such as rivers, streams, meadows and steep mountain slopes. The area is located in the dry temperate region comprising typical vegetation which disappears completely on the eastern slopes, dominated by a variety of economical species which play an important role in the rural life. The inhabitants are dependent on plant resources for food, fuel, timber, shelter, fodder/forage, household articles and traditional medicines in treating diseases like malaria, cancer, gastro-intestinal ailments, etc. This paper deals with the observations on traditional therapeutic application by the inhabitants of Paddar Valley. The ethno-botanical information on medicinal plants would not only be useful in conservation of traditional cultures and biodiversity but also community health care and drug development. Exploration survey in Paddar Valley has revealed that people collect and sell these medicinal species through local intermediaries / contractors to earn their livelihood. But the scientific cultivation and appropriate post-harvest management would improve employment opportunity and income of local farmers in the region.
\end{abstract}

Key words: Ethno-botanical; medicinal plants; Paddar valley; Jammu and Kashmir

\section{Introduction}

Herbal wealth comprising herbs and shrubs is an indispensable component of human lives since they provide diverse range of biochemical compounds required for metabolic activities (Cotton 1996; Buckingham 1999).

Western Himalayas are considered as a storehouse of herbal wealth supporting the vast network of traditional Indian System of Medicine. There is a wealth of information on the identity and distribution of different plant species of the region in the form of regional floras, reports of botanical expeditions, monographic accounts of families, genera and similar other publications. Ethno-botanical studies on medicinal plants are of paramount importance, particularly in the harsh climates like cold arid regions wherein modern system of medicine is not so developed. Such indigenous system of traditional knowledge conserves cultural and ecological diversity besides community healthcare and drug development. Ethno-botanical studies are also expected to provide new material for the ever-expanding pharmaceutical industry. Paddar Valley is the farthest corner of District Kishtwar, comprising 32 villages on south-eastern side touching its borders with Himachal Pradesh, Zanskar Valley of Ladakh and MarwahWadwan Valley. Paddar is known for blue diamond 'Sapphire' deposits and other forest products like kala zeera and guchhi. The area is drained by the Chenab river system which, flowing in from neighbouring Himachal Pradesh, enters the area through Paddar, the trans-Himalayan trekking trails leading to the Suru and Zanskar valleys of Ladakh pass amidst breathtaking mountain sceneries. Elevation range of the valley is 1500 to 4500 metres above mean sea level and between latitude $33^{\circ} 15^{\prime} 10^{\prime \prime} \mathrm{N}$ to $33^{\circ} 30^{\prime}$ $10^{\prime \prime} \mathrm{N}$ and longitude $76^{\circ} 02^{\prime} 10^{\prime \prime} \mathrm{E}$ to $76^{\circ} 25^{\prime} 15^{\prime \prime} \mathrm{E}$. This area remains considerably under the clouds when monsoon attacks the plains. Average temperature during the working season of July to September remains around $5^{\circ} \mathrm{C}$ to $10^{\circ} \mathrm{C}$ during the day and almost minus $1-2^{\circ} \mathrm{C}$ during night.

The region provides a wide variety of plants (herbs, shrubs and trees) owing to its diversified landscapes. Every year, thousands of people undertake Machail pilgrimage along Bhot nala, a tributary of River Chenab. The local inhabitants largely depended upon the local flora for food and medicine. The information on these plant species is utilised to understand the humanplant relationship, as well as a guide for drug development under the assumption that a plant which has been used by indigenous people over a long period of time may have an allopathic application (Farnsworth, 1993). Due to the remoteness of the area and dearth of doctors, the 'hakims' resorted to different medicinal plants as a treatment to different diseases (Arshad, 1999; Shinwari, 2002). The decline in their cultural peculiarities and their traditional knowledge about the local floras are spontaneous and fast due to better facilities of transportation, communication and education. Thus, the present study was carried out as an ethnobotanical exploration to collect and document information on useful plant species (their local names) that find traditional use in the daily life of local inhabitants for medicines and healthcare. 


\section{Materials and Methods}

An ethno-botanical survey of the Paddar valley has been carried out for the collection of specimen, traditional information and anthropological aspects. The practice of prescription and preparation of medicine by using local herbs has been observed at various locations in villages.

Regular exploration trips were made to the representative areas and different plant specimens were photographed, collected, dried, documented and were identified both by comparing them with herbarium specimen and with the help of flora of Jammu and other floras for confirmation (Stewart, 1967; 1982). First hand information on traditional knowledge related to plant resources, socio-economic and ethno-botanical information was recorded by interviewing the villagers, shopkeepers, timber dealers, local hakims and farmers, but priority was given to local elderly people and Hakims (Local health practitioners) who were the real traditional experts in the use of these medicinal plants. The information on local use of the plant species, their local names and parts used was recorded through discussions with the knowledgeable and elderly local people. They have been highlighted giving botanical names, local/common name(s), economic parts used, and prominent uses.

\section{Results and discussion}

The floral diversity of the valley has importance in traditional system of medicine due to its multifarious uses among the rural tribes. Local people are well versed in the use of plants for curing many ailments. Those associated with collection of medicinal plants from the forest areas generally sell them to the local practitioners, contractors or vendors to earn their livelihood. Information on important plant species with ethno-botanical importance has been presented in Table 1 and shown in Figures 1 (af) \& 2 (a-f).

Table 1: Ethno-botanical plant species used as medicines in Paddar Valley (J\&K)

\begin{tabular}{|c|c|c|c|c|}
\hline Name of the species & Local name & Family & $\begin{array}{l}\text { Official } \\
\text { part used }\end{array}$ & Important uses \\
\hline Achillea millefolium L. & Bergeur, Gandana & Asteraceae & Leaves & $\begin{array}{l}\text { Leaf infusion against stomach- } \\
\text { ache, cold and as tonic }\end{array}$ \\
\hline $\begin{array}{l}\text { Aconitum heterophyllum } \\
\text { Wall.ex Royale }\end{array}$ & Patrees & Ranunculaceae & Roots & $\begin{array}{l}\text { Used against diarrhoea, general } \\
\text { weakness, impotency and fever }\end{array}$ \\
\hline Allium corolinianum DC. & $\begin{array}{l}\text { Praan, } \\
\text { Gogcheegma }\end{array}$ & Amaryllidaceae & Bulbs & $\begin{array}{l}\text { Indigestion and in cooking } \\
\text { pulses and vegetables by the } \\
\text { nomads }\end{array}$ \\
\hline $\begin{array}{l}\text { Angelica glauca } \\
\text { Edgew }\end{array}$ & Choru, Chohore & Umbelliferae & Roots & Roots as spice and condiment \\
\hline Aquilegia fragrans Benth & $\begin{array}{l}\text { Kalumb, Jangli } \\
\text { kuth }\end{array}$ & Ranunculaceae & Roots & $\begin{array}{l}\text { Cystitis, gout, eczema, psoriasis } \\
\text { and blood sugar }\end{array}$ \\
\hline $\begin{array}{l}\text { Arnebia euchroma (Royale) } \\
\text { Johnston }\end{array}$ & Ratanjot & Boraginaceae & Roots & $\begin{array}{l}\text { Anti-inflammatory, eye- } \\
\text { diseases, cuts \& wounds, tooth } \\
\text { ache, anti-microbial, antipyretic } \\
\text { and ear ache }\end{array}$ \\
\hline $\begin{array}{l}\text { Artemisia brevifolia Wall.ex } \\
\text { DC. }\end{array}$ & $\begin{array}{l}\text { Moori, Joon, } \\
\text { tarkha }\end{array}$ & Asteraceae & Leaves & $\begin{array}{l}\text { Stomach-ache, intestinal } \\
\text { worms, appetite stimulant }\end{array}$ \\
\hline Atropa accuminata Royale & Jala kafal & Solanaceae & Root & $\begin{array}{l}\text { Anti-asthmatic, anti-spasmodic, } \\
\text { diuretic, tonic and aphrodisiac }\end{array}$ \\
\hline Berberis lycium Royale & $\begin{array}{l}\text { Daruhaldi, } \\
\text { khawaray }\end{array}$ & Berberidaceae & Fruits, roots & $\begin{array}{l}\text { Fruit extract against stomach- } \\
\text { ache and diarrhoea, jaundice } \\
\text { and liver diseases, roots extract } \\
\text { called 'Rasaunt' used as } \\
\text { cooling agent and eye lotion }\end{array}$ \\
\hline $\begin{array}{l}\text { Bergenia ciliata } \text { (Hook } \\
\text { f.Thomas) Engl. }\end{array}$ & $\begin{array}{l}\text { Zakham-a-hayat, } \\
\text { sapdotri }\end{array}$ & Saxifragaceae & Roots & $\begin{array}{l}\text { Massage to cure body swelling, } \\
\text { kidney stones, wound healing, } \\
\text { cosmetics, etc. }\end{array}$ \\
\hline Bunium persicum $\mathrm{L}$ & $\begin{array}{l}\text { Kala zeera, sia } \\
\text { zeera }\end{array}$ & Apiaceae & Seeds & $\begin{array}{l}\text { Seed as spice, appetiser, } \\
\text { reduces cholesterol, anxiety and } \\
\text { depression, indigestion, } \\
\text { dysentery, carminative, } \\
\text { bronchitis, diseases of blood } \\
\text { and ear, leprosy and } \\
\text { convulsions. }\end{array}$ \\
\hline Codonopsis rotundifolia Benth & Bibdi & Companulaceae & Fruit & Eaten as vegetable, roots are \\
\hline
\end{tabular}


Gupta et al., Afr J Tradit Complement Altern Med. (2013) 10(4):59-65 http://dx.doi.org/10.4314/ajtcam.v10i4.10

\begin{tabular}{|c|c|c|c|c|}
\hline & ( Paddri) & & & aphrodisiac \\
\hline Colchicum leutum Baker & Chingposh & Liliaceae & Corms & $\begin{array}{l}\text { Rheumatism, gout, diseases of } \\
\text { liver and spleen }\end{array}$ \\
\hline $\begin{array}{ll}\text { Dactylorhiza } & \text { hetagirea } \\
\text { (D.Don) Soo } & \\
\end{array}$ & $\begin{array}{ll}\text { Salam panja, } \\
\text { hathpanja }\end{array}$ & Orchidaceae & Roots & $\begin{array}{l}\text { Round worms of stomach, } \\
\text { inducing pus formation in boils }\end{array}$ \\
\hline $\begin{array}{l}\text { Delphinium brunonianum } \\
\text { Wall. }\end{array}$ & $\begin{array}{l}\text { Nirvisha, } \\
\text { Changuathpa }\end{array}$ & Ranunculaceae & Whole plant & Diabetes \\
\hline $\begin{array}{l}\text { Ephedra gegardiana Wall.Ex } \\
\text { Stapf }\end{array}$ & $\begin{array}{l}\text { Tutfoor, Rachi, } \\
\text { trudak }\end{array}$ & Epherdraceae & Twigs & $\begin{array}{l}\text { Asthma, cardiac stimulant hay } \\
\text { fever, rashes of allergic origin, } \\
\text { respiratory disorder rand } \\
\text { sunburn }\end{array}$ \\
\hline Eremurus himailicus Baker & $\begin{array}{l}\text { Prezdar, Kaahlu } \\
\text { ( Paddri) }\end{array}$ & Asphodelaceae & $\begin{array}{l}\text { Leaves, } \\
\text { Roots }\end{array}$ & $\begin{array}{l}\text { As leafy vegetable, even roots } \\
\text { are cooked when young foliage } \\
\text { is mature and not fit for eating }\end{array}$ \\
\hline Gentiana kurroo Royale & Neel kanth, Tikta & Gentianaceae & Whole plant & $\begin{array}{l}\text { Blood purifier, fever, cough, } \\
\text { liver ailments and headache }\end{array}$ \\
\hline Geranium pretense L. & $\begin{array}{l}\text { Gugchuk, } \\
\text { ringresh }\end{array}$ & Geraniaceae & Leaves & Diarrhoea and dysentery \\
\hline Hippophae rhamnoides L. & $\begin{array}{l}\text { Charma, tirku, } \\
\text { buru }\end{array}$ & Elaeagnaceae & Fruits & $\begin{array}{l}\text { Improvement of digestion, anti- } \\
\text { oxidants, tumours, liver } \\
\text { ailments, eye ailments, } \\
\text { bronchial asthma, skin wrinkles } \\
\text { and high cholesterol }\end{array}$ \\
\hline Hyoscymous niger L. & $\begin{array}{l}\text { Bajerbhang, murg } \\
\text { jawain }\end{array}$ & Solanaceae & $\begin{array}{l}\text { Leaves, } \\
\text { flowers }\end{array}$ & $\begin{array}{l}\text { Nervousness, asthma, and } \\
\text { whooping cough. }\end{array}$ \\
\hline Hyssopus officinalis L. & Tengu, tyangu & Lamiaceae & Flowers & $\begin{array}{l}\text { Substitute for saffron, in } \\
\text { Tibetan medicine, liver and } \\
\text { blood disorders }\end{array}$ \\
\hline $\begin{array}{l}\text { Inula racemosa Hook.f. } \\
\text { royleana }\end{array}$ & Poshkarmool & Asteraceae & Roots & $\begin{array}{l}\text { Anti-inflammatory, anti- } \\
\text { pyretic, anti-asthmatic, } \\
\text { antiseptic }\end{array}$ \\
\hline Juniperus communis L. & Bethri, Dhoop & Cupressaceae & $\begin{array}{l}\text { Flowers, } \\
\text { fruits }\end{array}$ & $\begin{array}{l}\text { Carminative, curing asthma, } \\
\text { against swellings, tumours, } \\
\text { warts, stimulant and diuretic }\end{array}$ \\
\hline $\begin{array}{l}\text { Jurinea dolomiaea (Royale) } \\
\text { C.B. Clarke }\end{array}$ & Dhoop, guggal & Asteraceae & Roots & Dhoop making \\
\hline $\begin{array}{ll}\text { Lavatera cashmeriana } \\
\text { Cambess }\end{array}$ & Gursaunchal & Malvaceae & Roots & $\begin{array}{l}\text { Roots recommended in } \\
\text { respiratory complaints }\end{array}$ \\
\hline $\begin{array}{l}\text { Morina Longifolia Wall ex } \\
\text { DC. }\end{array}$ & Kandmool, kim & Dipsacaceae & Roots & Wounds, incense, dhoops \\
\hline $\begin{array}{l}\text { Onosoma hispidia Wall.ex } \\
\text { G.Don. }\end{array}$ & $\begin{array}{l}\text { Ratanjot, } \\
\text { ratmundi }\end{array}$ & Boraginaceae & Root & $\begin{array}{l}\text { Rheumatism, heat disorders, } \\
\text { hair treatment }\end{array}$ \\
\hline $\begin{array}{l}\text { Picrrorhiza kurroo Royale ex } \\
\text { Benth }\end{array}$ & $\begin{array}{l}\text { Kuru, kaur, } \\
\text { Honglen }\end{array}$ & Scrophulariaceae & $\begin{array}{l}\text { Flower, } \\
\text { rhizomes }\end{array}$ & $\begin{array}{l}\text { Fever, hepatoprotective, tonic } \\
\text { to improve appetite, rheumatic } \\
\text { arthritis }\end{array}$ \\
\hline Plantago depressa Willd. & $\begin{array}{lr}\text { Van } & \text { isabgol, } \\
\text { chapach } & \text { patri, } \\
\text { Tharam } & \\
\end{array}$ & Plantaginaceae & Whole plant & $\begin{array}{l}\text { Infusion against gastro- } \\
\text { intestinal } \\
\text { dysentery and anti-diarrhoeal }\end{array}$ \\
\hline $\begin{array}{ll}\text { Podophyllum } & \text { hexandrum } \\
\text { Royale } & \end{array}$ & $\begin{array}{l}\text { Bankakru, } \\
\text { Rhodadari }\end{array}$ & Podophyllaceae & $\begin{array}{l}\text { Rhizome, } \\
\text { roots }\end{array}$ & $\begin{array}{l}\text { Hepatic, stimulant, diarrhoea, } \\
\text { purgative, liver ailments and } \\
\text { cancer treatment }\end{array}$ \\
\hline Polygonatum verticillatum L. & $\begin{array}{l}\text { Salam dana, } \\
\text { mishri, mitha- } \\
\text { dodhu }\end{array}$ & Liliaceae & Roots & $\begin{array}{l}\text { Appetiser, backache and } \\
\text { menstrual troubles }\end{array}$ \\
\hline $\begin{array}{l}\text { Ranunculus trichophyllus } \\
\text { Chaix. }\end{array}$ & Rengo & Ranunculaceae & Whole plant & Diarrhoea \\
\hline $\begin{array}{l}\text { Rheum australe Wall ex } \\
\text { Weissn }\end{array}$ & $\begin{array}{l}\text { Padshah, } \\
\text { pambchalan, }\end{array}$ & Polygonaceae & Roots & $\begin{array}{l}\text { Stomach-ache, cuts and } \\
\text { wounds, muscular swellings } \\
\text { and mumps, dye woollens }\end{array}$ \\
\hline Rheum webbianum Royale. & Lachhu & Polygonaceae & Roots & $\begin{array}{l}\text { Chronic diarrhoea, tender } \\
\text { shoots and leaves as vegetable }\end{array}$ \\
\hline
\end{tabular}


Gupta et al., Afr J Tradit Complement Altern Med. (2013) 10(4):59-65 http://dx.doi.org/10.4314/ajtcam.v10i4.10

\begin{tabular}{|c|c|c|c|c|}
\hline $\begin{array}{l}\text { Saussurea simpsoniana (Field. } \\
\text { \& Gardn.) Lipsch }\end{array}$ & $\begin{array}{l}\text { Yogi padshah, } \\
\text { Jogi phool }\end{array}$ & Asteraceae & Whole plant & $\begin{array}{l}\text { Asthma, gynaecological } \\
\text { problems }\end{array}$ \\
\hline Saussurea costus Clarke & $\begin{array}{l}\text { Kuth, Kuste } \\
\text { Himid }\end{array}$ & Asteraceae & Roots & $\begin{array}{l}\text { Asthma, bronchitis, cough, } \\
\text { dental troubles, dysentery, } \\
\text { hysteria, heart problems and } \\
\text { menstruation trouble }\end{array}$ \\
\hline $\begin{array}{l}\text { Saussurea obvallata Wall.Ex } \\
\text { CB Clarke }\end{array}$ & Jogi gag, Pangehi & Asteraceae & Bracts & $\begin{array}{lll}\begin{array}{l}\text { Cough } \\
\text { problems }\end{array} & \text { and } & \text { respiratory } \\
\end{array}$ \\
\hline Sedum ewersii Ledeb. & $\begin{array}{l}\text { Shrolu, aggjadi, } \\
\text { Shurupa }\end{array}$ & Crassulaceae & $\begin{array}{l}\text { Shoots and } \\
\text { leaves }\end{array}$ & $\begin{array}{l}\text { Dysentery, healing of wounds } \\
\text { and burns by gujjars }\end{array}$ \\
\hline $\begin{array}{llll}\text { Swertia cordata } & \text { (Wall ex } \\
\text { G.Don) } & & & \\
\end{array}$ & Chirayata, Tikta & Gentianaceae & Whole plant & $\begin{array}{l}\text { Stomach-ache, antipyretic, } \\
\text { cough, joint pains, leucoderma }\end{array}$ \\
\hline $\begin{array}{l}\text { Tanacetum dolichophyllum } \\
\text { (Kitam.) }\end{array}$ & Lidd guggli & Asteraceae & $\begin{array}{l}\text { Leaves, } \\
\text { flowers, } \\
\text { roots }\end{array}$ & $\begin{array}{l}\text { Intestinal worms, roots as } \\
\text { incense }\end{array}$ \\
\hline Taraxacum officinale Wigg. & $\begin{array}{l}\text { Handri, Sanma, } \\
\text { zear-gulay }\end{array}$ & Asteraceae & $\begin{array}{l}\text { Roots, } \\
\text { flowers }\end{array}$ & $\begin{array}{l}\text { Tonic, stimulant, laxative, } \\
\text { stomach disorders, indigestion } \\
\text { and intestinal worms, roots and } \\
\text { leaves as vegetable, flowers in } \\
\text { making alcoholic drink }\end{array}$ \\
\hline Thermopsis inflata Cambess & Lamo & Papilionaceae & Whole plant & Remove water from the body \\
\hline Thymus serphyllum L. & $\begin{array}{l}\text { Van jawain, } \\
\text { marchi, }\end{array}$ & Lamiaceae & Whole plant & $\begin{array}{l}\text { Whooping cough, epilepsy, } \\
\text { suppression of urine and } \\
\text { menstrual catarrh, tea } \\
\text { substitute, roots used in havan }\end{array}$ \\
\hline Valeriana jatamansi Jones & Mushkbala & Valerianaceae & Roots & $\begin{array}{l}\text { Tranquiliser and sedative } \\
\text { action, in perfumes }\end{array}$ \\
\hline Viola serpens Blume & Banfsha & Violaceae & Whole plant & Cough and cold \\
\hline
\end{tabular}

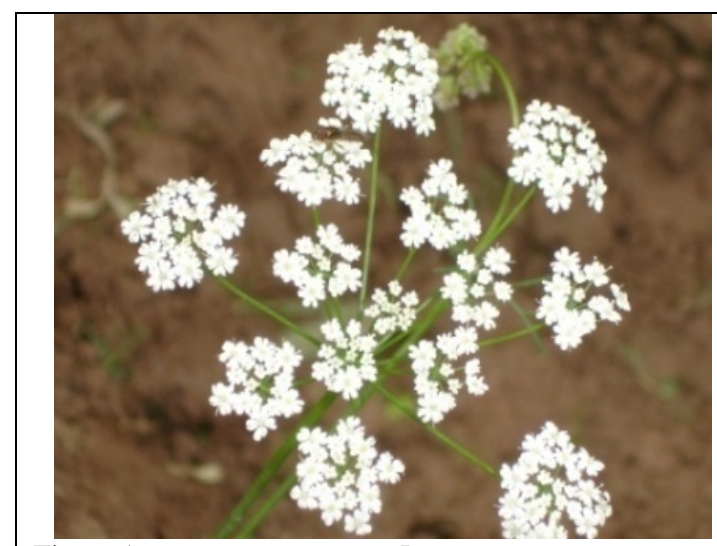

Figure 1a. Bunium persicum L.

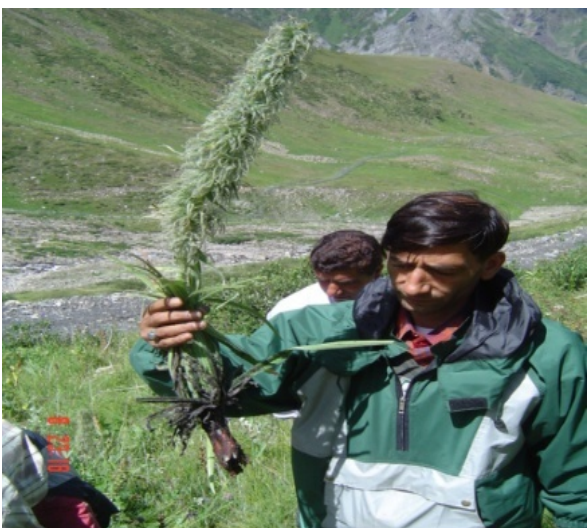

Figure 1b. Arnebia euchroma (Royale) Johnston 
Gupta et al., Afr J Tradit Complement Altern Med. (2013) 10(4):59-65 http://dx.doi.org/10.4314/ajtcam.v10i4.10

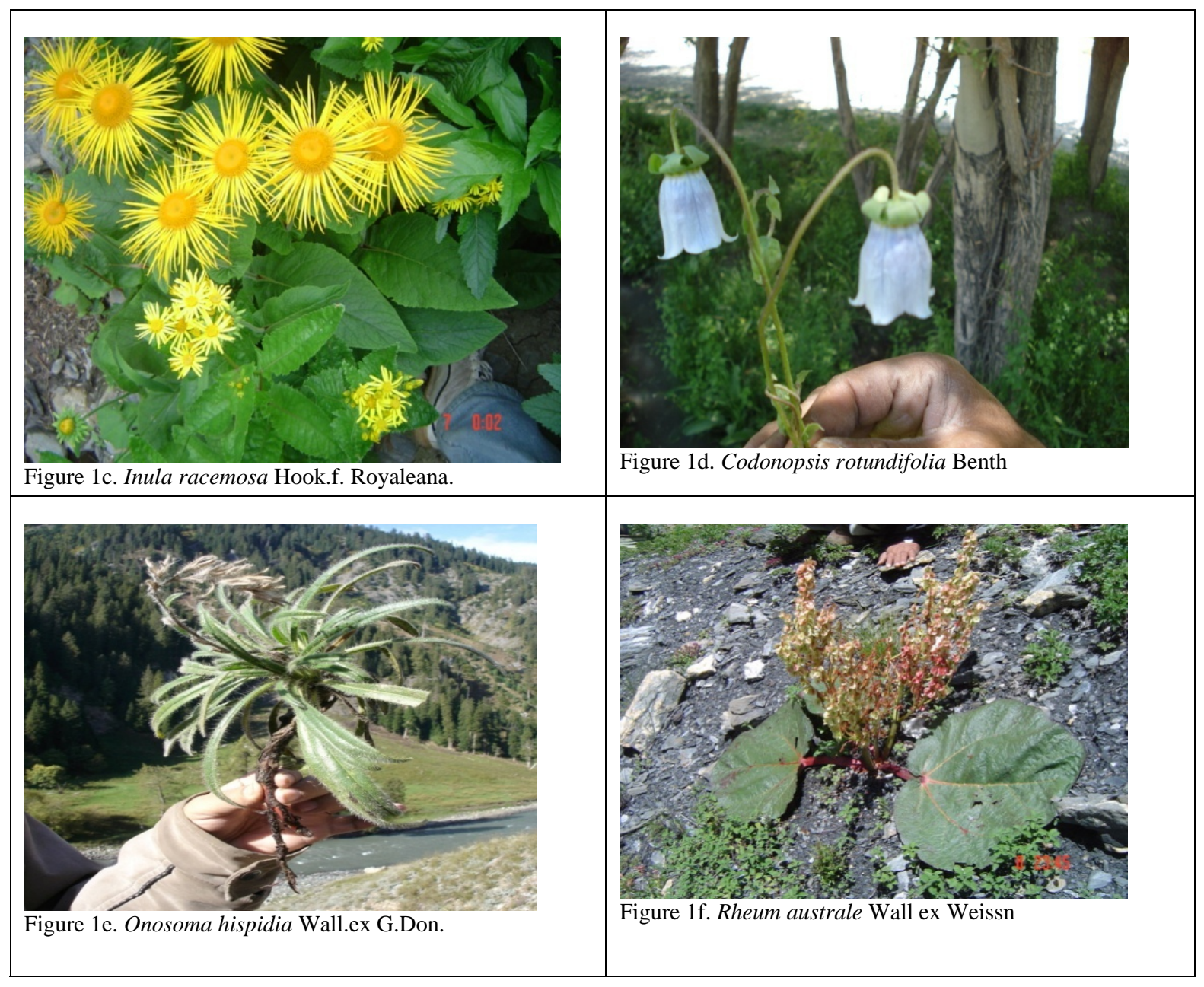

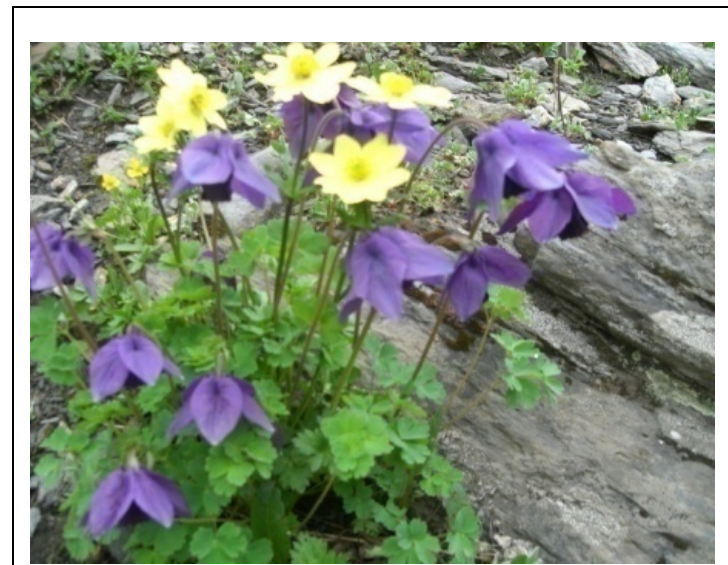

Figure 2 a. Aquilegia fragrans Benth.

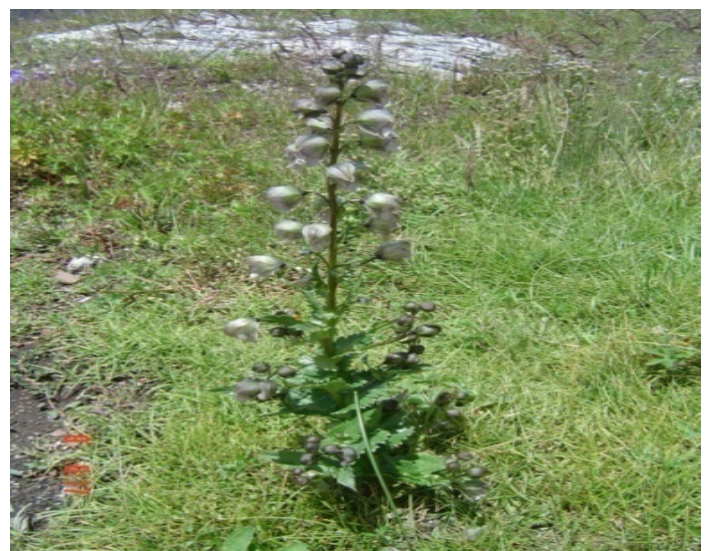

Figure 2b. Aconitum heterophyllum Wall.ex Royale 


\section{Gupta et al., Afr J Tradit Complement Altern Med. (2013) 10(4):59-65 http://dx.doi.org/10.4314/ajtcam.v10i4.10}

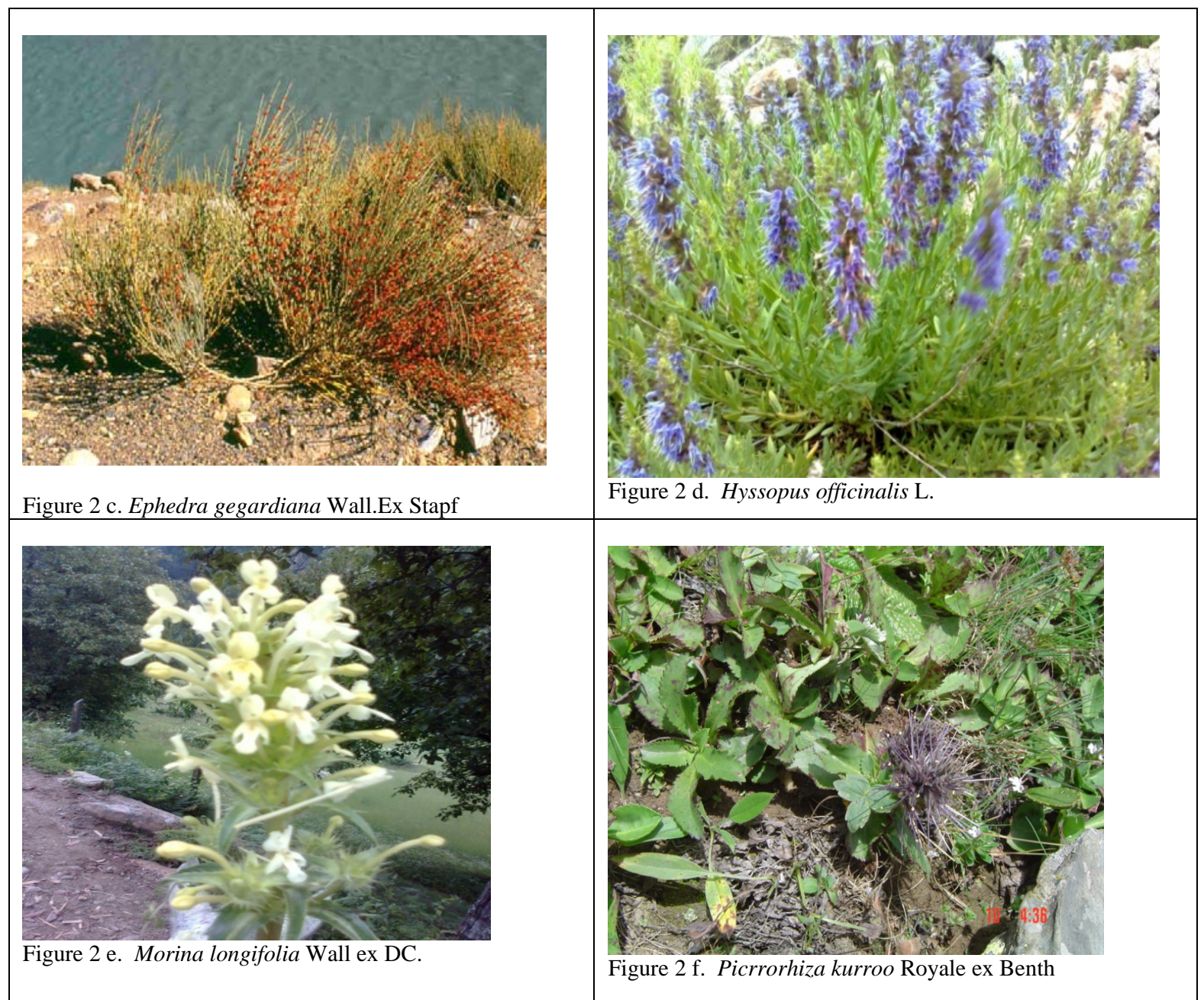

Such types of ethno-medico-botanical surveys have also been conducted in different agro-ecological regions by Kapoor and Sarin (1963); Kachroo et al. (1977); Chauhan (1997); Sharma (1998); Sharma and Rana (1999); Chaurasia et al. (1999); Vidarathi (1997; 2003); Singh and Chauhan (2005), and Gupta (2011) who have all documented the different plant species of ethno-botanical importance in different regions.

Over-exploitation of these species has not only degraded the local vegetation and the disappearing of natural beauty but also endangered certain species, and one has to travel miles to find them. The direct causes such as cutting of forests for commercial and subsistence purposes and indiscriminate grazing, as well as indirect causes such as insecure land tenure, poverty and population growth, were the most vital factors affecting the local flora. Harsh climatic and high altitude conditions and inaccessibility are the factors which force the people to depend on wild flora for healthcare. There is a negligible attitude towards the cultivation of these herbs. Some of these plants are only found to grow in the forest and grassy slopes and very few find place in the people's home gardens. Therefore, there is a dire need for the protection of this wealth of nature before it disappears from this planet. Moreover, this type of study would be essential for regeneration, conservation and reforestation of this niche area. The altitudinal variation in vegetation was also observed in the zone. The present study disclosed that the growing season was too small starting from April up to September only. The bottlenecks in enhancing the livelihood of the people by using traditional knowledge included inaccessibility of the area, lack of processing and adequate storage after harvest, legal restrictions due to forest legislations, inadequate market and assured prices.

The region should be developed with special interest to the rare availability and high value herbs in comparison with the cultivation of un-economical food crops and shift in the production and marketing of medicinal plants in an organised manner. Therefore, all efforts made to conserve the threatened herbal species and promotion of their cultivation either in-situ or ex-situ by the coordinated efforts of the research and development organisations would go a long way in improving the socio-economic status of and in preserving the traditional knowledge and resources of this region. 


\section{Gupta et al., Afr J Tradit Complement Altern Med. (2013) 10(4):59-65 http://dx.doi.org/10.4314/ajtcam.v10i4.10}

\section{Acknowledgements}

The senior author is highly thankful to the Horticulture Technology Mission, Government of India for giving an opportunity to work in the area in one of its research projects. The help rendered by the local elderly people of Paddar Valley in providing the information about the traditional use and identification of the plant samples is also highly acknowledged.

\section{References}

1. Arshad, M., Akram, S. (1999). Medicinal plants of University of Arid Agriculture, Rawalpindi. Hamdard Med., 42:46-49.

2. Buckingham, J. (1999). Dictionary of Natural Compounds. Chapman and Hall, U.K: 14-20.

3. Chauhan, N.S. (1997). Ecological and Ethanobotanical studies on the flora of Spiti, Himachal Pradesh. Ph.D Thesis submitted to Department of Biosciences, Himachal Pradesh University, Shimla, (HP) India, 254p.

4. Chaurasia, O.P., Brahma, S., Sreen, S.K. (1999). Ethno-medico-botany survey of Nubra Valley. Journal of Economic and Taxonomic Botany 23 (1): 167-172.

5. Cotton, C.M. (1996). Ethnobotany: Principals and Applications. John Wiley and Sons Ltd., Chichister, England.

6. Farnsworth, N.R. (1993). Ethnopharmacology and future drug development: The North American experience. $J$. Ethnopharmacol., 38: 145-152.

7. Gupta, Arun (2011). Ethnobotanical studies on Gaddi Tribe of Bharmour area of Himachal Pradesh. Ph.D Thesis Dr.YSP University of Horticulture \& Forestry, Nauni, (Solan) India, 155p.

8. Kachroo, P., Sapru, B.L., Dhar, U. (1977). Flora of Ladakh. Bishen Singh Mahinder Pal Singh, Dehradun, 172 p.

9. Kapoor, S.K., Sarin Y.K. (1963). Flora of Trikuta hills (Shri Vaishno Devi Shrine) woth special reference to the distribution pattern of minor forest products. Bishen Singh Mahinder Pal Singh, Dehradun, 267 p.

10. Sharma, B.D., Rana, J.C. (1999). Traditional uses of plants of Himachal Pradesh. Journal of Economic and Taxonomic Botany 23 (1): 173-176

11. Sharma, P.K. (1998). Ethnobotanical studies on Gaddies- A tribal community in district Kangra (HP).M.Sc. Thesis Dr.YSP University of Horticulture \& Forestry, Nauni, (Solan) India, 108 p.

12. Shinwari, Z.K., Gilani, S.S., M. Akhlas. (2002). Sustainable harvest of medicinal plants at Bar and Shinakii valleys, Gilgit. Consultancy Report: WWF-P.

13. Singh, V., Chauhan, N.S. (2005). Traditional practices of herbal medicines in the Lauhal Valley, Himachal Himalayas. Indian Journal of Traditional Knowledge 4 (2): 208-220.

14. Stewart, R.R. (1967). Checklist of plants Swat state, Northwest Pakistan. Pak. J. For., 4(2): 457-528.

15. Stewart, R.R. (1982). History and exploration of plants in Pakistan and adjoining areas, National Herbarium, NARC, Islamabad.

16. Vidarathi, O.P. (1997). Wild and cultivated plants of Jammu, Kashmir and Ladakh, Directorate of Social Forestry, Jammu and Kashmir.

17. Vidarathi, O.P. (2003). Medicinal plants of plains and hills. Mansi Prakashan, Panjthirthi, Jammu, Jammu and Kashmir. 